\title{
Effect of different Nitrogen fertilization on cabbage (Brassica oleracea) and development of diamondback moth (Plutella xylostella)
}

\author{
${ }^{1}$ Fatimah, S.N., ${ }^{1,2}$ Norida, M. and ${ }^{3}$ Zaharah, S.S. \\ ${ }^{1}$ Department of Agricultural Technology, Faculty of Agriculture, Universiti Putra Malaysia, 43400 UPM \\ Serdang, Selangor, Malaysia \\ ${ }^{2}$ Laboratory Climate-Smart Food Crop Production, Institute Tropical Agriculture and Food Security, \\ Universiti Putra Malaysia, 43400 UPM Serdang, Selangor, Malaysia \\ ${ }^{3}$ Department of Crop Science, Faculty of Agriculture, Universiti Putra Malaysia, 43400 UPM Serdang, \\ Selangor, Malaysia
}

\begin{abstract}
Article history:
Received: 24 October 2018 Received in revised form: 7 December 2018

Accepted: 19 December 2018 Available Online: 23

December 2018
\end{abstract}

Keywords:

Development,

Fertilization,

Insect-Plant interaction, Nitrogen

DOI:

https://doi.org/10.26656/fr.2017.3(4).150

\begin{abstract}
Cabbage (Brassica oleracea var. capitata) contains highly nutritional values compared to other leafy vegetables in tropical areas. This vegetable requires an adequate amount of plant nutrients for growth and development. Nitrogen $(\mathrm{N})$ fertilization can improve plant qualities, but at the same time, it may also lead to higher levels of pest damage to crops. Diamondback moth (DBM) is one of the major insect pests attacking cabbage thus reducing the profitable cabbage production. This study is to demonstrate the effect of $\mathrm{N}$ on the plant growth and response of the insect pest towards higher $\mathrm{N}$ fertilization. Cabbage were applied with different $\mathrm{N}$ level; control; $50 \mathrm{mg} / \mathrm{L}, 100 \mathrm{mg} / \mathrm{L}, 150 \mathrm{mg} / \mathrm{L}, 200 \mathrm{mg} / \mathrm{L}$ and $300 \mathrm{mg} / \mathrm{L}$ at $2^{\text {nd }}$ and $4^{\text {th }}$ week after transplanting. At $6^{\text {th }}$ week, treatment with higher $\mathrm{N}$ enhances the growth and development of cabbage and fastens the development of DBM. Glucosinolate content in cabbage was higher at $6^{\text {th }}$ week compared to $9^{\text {th }}$ and $12^{\text {th }}$ weeks. It was further concluded that $\mathrm{N}$ fertilizer can increase cabbage productivity and understanding to learn chemical ecology and insect behaviour are crucial to develop pest control approaches.
\end{abstract}

\section{Introduction}

Cabbage (Brassica oleracea var. capitata L.) from family Cruciferae has been recognized as one of the top twenty vegetables and significant food sources around the world. Currently, cabbage has risen as main valued fresh market and widely marketed as minimally processed product. In Malaysia, its total production is about 101,258 metric tonnes (DOA, 2016). Cabbage is rich with nutritional values such as vitamin $C$, minerals and a small amount of protein with good caloric value (Singh et al., 2006) and glucosinolate (Song and Tornalley, 2007). To achieve marketable with high nutritional quality cabbage, the agronomic practices which highly dependent on $\mathrm{N}$ fertilizer is required. Lack of $\mathrm{N}$ causes stunted growth or leaves discoloration in green cabbage. However, excessive applied of $\mathrm{N}$ fertilizer contributes to nitrate build up in soil and vegetables (Manchali et al., 2012).

Diamondback moth, Plutella xylostella L. (Lepidoptera: Plutellidae) is the most damaging insect pest of cruciferous crops in the world (Talekar and
Shelton 1993; Grzywacz et al., 2010) and one of the major constraints to high profitable cabbage production. Total loss of the plant caused by DBM worldwide has increased per annum (Furlong et al., 2013). In Malaysia, DBM is among major pest of crucifer in Cameron Highlands and in the lowlands since 1941 (Corbett and Pagden, 1941). To meet the demand by consumers, farmers often applied excess fertilizer to obtain high yields in the form of nitrogen-based fertilizers and thus influencing the preference and performance of insect pest on the plant. In addition, almost $90 \%$ of the farmers utilize insecticides as primary control to combat DBM infestation on cruciferous crop. Consequently, these practices cause arising environmental problem and lead DBM to resistant as well as the rejection of harvested crops by consumer due to highly pesticide residue in crucifer. The objectives of this study were to determine the effects of different $\mathrm{N}$ levels on the growth and development of cabbage and its major pest DBM.

\section{Materials and methods}

\subsection{Plant growth experiment}


Cabbage plants were grown individually in a round pot $(12 \mathrm{~cm} \times 11 \mathrm{~cm})$ using topsoil: sand: organic matter with ratio $3: 2: 1$ as a potting medium. Experimental plants were laid out in a split plot design (SPD) with six different levels of $\mathrm{N}$ treatments (T1: Control; T2: $50 \mathrm{mg} /$ $\mathrm{L}$; T3: $100 \mathrm{mg} / \mathrm{L}$; T4:150 mg/L; T5: $200 \mathrm{mg} / \mathrm{L}$ and T6: $300 \mathrm{mg} / \mathrm{L})$ at $2^{\text {nd }}$ and $4^{\text {th }}$ weeks after transplanting (WAT). The treatments were replicated five times. Plant growth data parameters including root length, leaf area, dry weight of root and leaves were collected subsequently chemical analysis of $\mathrm{N}$ and glucosinolate were analysed on 6,9 and 12 WAT.

\subsection{DBM development experiment}

DBM larva and pupae were collected from a private organic farm in Semenyih and was cultured on cruciferous plants in glasshouse. The cotton wool was dipped with $10 \%$ of honey solutions as food sources to adult DBM. 10 neonates of DBM were put on sixth-week old plants to observe the duration required of DBM to change from larva, pupae and adult. All the experiments were conducted with five replications.

\subsection{Statistical analysis}

The $\mathrm{N}$ effect on cabbage growth was evaluated by analysis of variance (ANOVA), the mean differences were tested with Duncan Multiple Range Test (DMRT) at $\mathrm{P}<0.05$. The effect of $\mathrm{N}$ on $\mathrm{DBM}$ growth was evaluated by analysis of PROC GLM for split-plot design.

\section{Results and discussion}

\subsection{Effects of nitrogen fertilization on cabbage growth}

The effect of $\mathrm{N}$ treatment had a significant difference on the root length $(\mathrm{P}<0.05)$ (Figure 1). It demonstrated that higher $\mathrm{N}$ uptake responds to the root elongation by increasing root length of cabbage with $27.97 \mathrm{~cm}$ after applied with $300 \mathrm{mg} / \mathrm{L}$ of $\mathrm{N}$ compared to other treatments. A similar result was reported by Petridis et al. (2012) showed that higher $\mathrm{N}$ treatments on lettuce

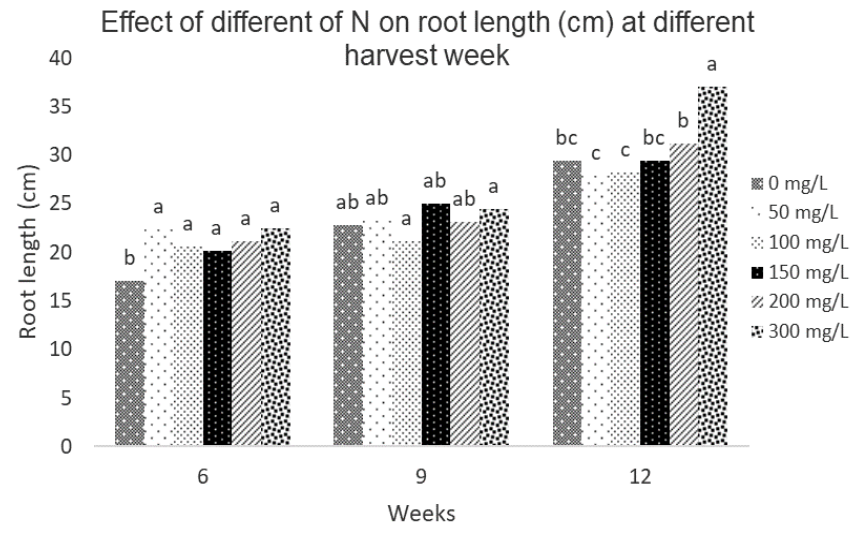

Figure 1. Means of cabbage root length (cm) at week 6, 9 and 12 of harvesting after treated with different $\mathrm{N}$ level had the longest root length compared to lower $\mathrm{N}$ treatments. This may explain that high $\mathrm{N}$ application plays a role in root elongation by absorbing mineral nutrients which is fundamental in metabolism. There was also a significant interaction between root length and different harvest week of cabbage $(\mathrm{P}<0.05)$. Longest root length was measured at week 12 with $36.98 \mathrm{~cm}$ after treated with $300 \mathrm{mg} / \mathrm{L}$ of $\mathrm{N}$.

Figure 2 shows that the roots dry weight were significantly different after grown with different $\mathrm{N}$ treatments $(\mathrm{P}<0.05)$. Similarly, Shormin and Kibria (2018) found that dry root weight of Indian spinach (Basella alba L.) increased positively with increasing levels of $\mathrm{N}$. There was a significant interaction between $\mathrm{N}$ level and different harvest week on the dry weight of roots $(\mathrm{P}<0.05)$ at Figure 2. Cabbage which grown with $300 \mathrm{mg} / \mathrm{L}$ of $\mathrm{N}$ at week 6 and 12 while $50 \mathrm{mg} / \mathrm{L}$ at week 9 gave higher roots dry weight.

There was a significant difference $(\mathrm{P}<0.05)$ among the $\mathrm{N}$ treatments on the dry weight of the leaves in Figure 3. Cabbage treated with $300 \mathrm{mg} / \mathrm{L}$ of $\mathrm{N}$ shown the highest dry leaf weight followed by $150 \mathrm{mg} / \mathrm{L}$ and 200 $\mathrm{mg} / \mathrm{L}$ of N. Previous study found application of higher N with increased leaves dry weight of lettuce (Boroujerdnia and Ansari, 2007). Tabeke et al. (1995) suggested that increasing leaf dry weight because of the $\mathrm{N}$ is combined with plant constituents of compounds during photosynthesis such as glucose, ascorbic acid, amino acid and protein. Moreover, increasing $\mathrm{N}$ fertilizer rate affected the leaf dry weight because $\mathrm{N}$ enhances plant photosynthesis, thus increasing dry matter production (Novoa and Loomis, 1981). There was also a significant interaction between $\mathrm{N}$ level and harvesting week on leaf dry weight in Figure 3. At the final stage of harvesting was shown highest leaf dry weight followed by week 9 and 6 where $300 \mathrm{mg} / \mathrm{L}$ of $\mathrm{N}$ had the highest leaves dry weight compared to other treatments.

A significant difference was observed between effect $\mathrm{N}$ treatments on the leaves area $(\mathrm{P}<0.05)$ in Table 1 .

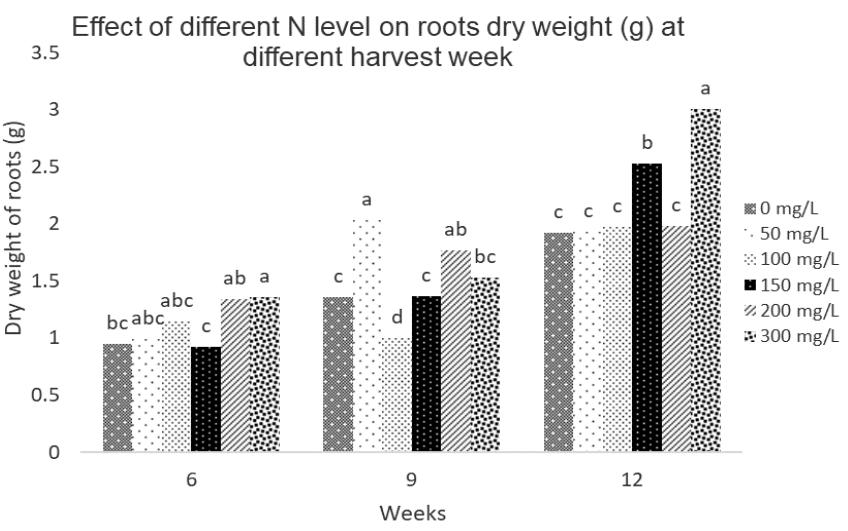

Figure 2. Means of roots dry weight of cabbage at week 6, 9 and 12 of harvesting after treated with different $\mathrm{N}$ level

C 2018 The Authors. Published by Rynnye Lyan Resources 
Higher $\mathrm{N}$ application resulted in the leaf expansion in the treated plants compared to control plants. An increase leaf development of swiss chard (Beta vulgaris L. var. cicla $\mathrm{L}$.) with an increase in $\mathrm{N}$ level was also reported by Miceli and Miceli (2014). There was also a significant interaction found between $\mathrm{N}$ treatments and different harvesting week on leaf area $(\mathrm{P}<0.05)$ in Table 1. This trend implied that higher $\mathrm{N}$ fertilizer promoted leaf expansion rate which is a dominant factor in determining the leaf area maturity. Thus, these resulted that cabbage required adequate amount of $\mathrm{N}$ at early growth of each development mainly use in the process enlargement of leaves. Well-developed of leaves contributed to the better head formation of cabbage.

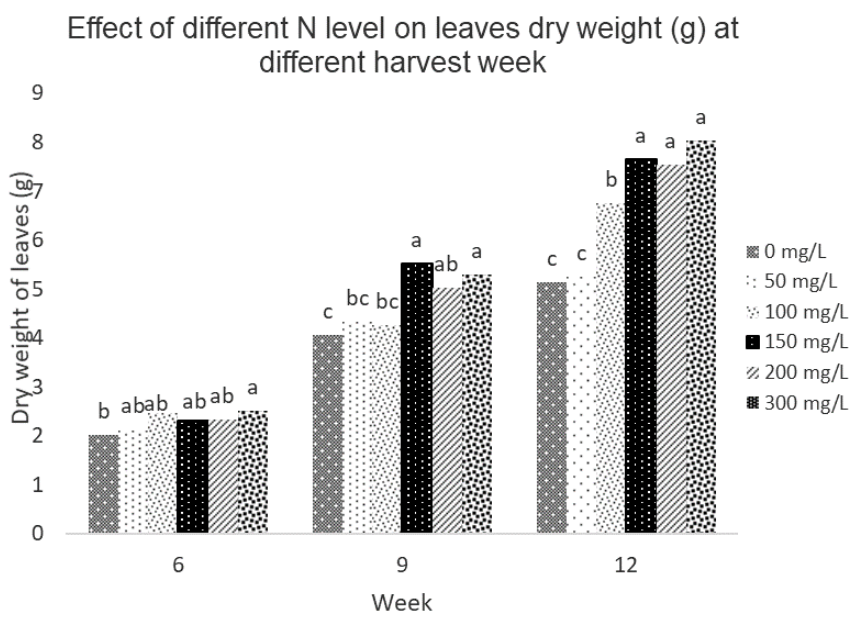

Figure 3. Means of leaves dry weight of cabbage at week 6, 9 and 12 of harvesting after treated with different $\mathrm{N}$ level

\subsection{Chemical analysis}

Table 2 showed that there was a significant effect of different $\mathrm{N}$ level on $\mathrm{N}$ content in leaves cabbage. Leaves treated with high level of $\mathrm{N}$ had higher $\mathrm{N}$ content than unfertilized plants. Engelbrecht et al. (2010) found that $\mathrm{N}$ content was higher in Beta vulgaris var cicla leaves after treated with high dose of N. Leong et al. (2004) also found that higher $\mathrm{N}$ had the highest percentage of $\mathrm{N}$ in cabbage compared to the lowest $\mathrm{N}$ rate. There was a significant interaction between $\mathrm{N}$ content in leaves and different harvesting week in Table 2. This due to the $\mathrm{N}$ content in leaves tissue declined as the stage of development progressed. It indicated $\mathrm{N}$ had absorbed at the early growth stages and reutilize for expansion leaves at the latter growth stages. Kamarudin et al. (2014) also revealed $\mathrm{N}$ concentration was higher at early stages of plant growth. Thus, the age of plant tissue is an important factor to determines $\mathrm{N}$ content.

Table 3 shows there was significant interaction of different $\mathrm{N}$ different between glucosinolate content in leaves and different harvesting weeks of cabbage. Glucosinolate content was greater on 6-week-old plants compared to 9 and 12 weeks after treated with different
$\mathrm{N}$ level. Young leaves contained higher levels of glucosinolate and reduce after maturation (Porter et al., 1991; Badenes-Perez et al., 2014). However, 150 mg/L of $\mathrm{N}$ shown the highest glucosinolate on 6-week-old in leaves cabbage. Velasco et al. (2007) revealed that higher $\mathrm{N}$ produces a decrease in total glucosinolates. Thus, glucosinolates content in plants varied among ontogenetic state of plant and agronomic factors related to its growth.

\subsection{DBM development}

Table 4 shows the application of $\mathrm{N}$ had a significant effect on DBM growth. $\mathrm{N}$ fertilization significantly reduced larva period compared to no treatments. The higher the amount $\mathrm{N}$, the shorter is the larva period. Similarly, DBM larvae developed faster when fed on cauliflower grown with higher dose of $\mathrm{N}$ (Bansode and Purohit, 2013). Hwang et al. (2008) reported that larvae fed on higher nutrient leaves had increase growth rate and reduce development time compared to larvae that fed on low nutrient leaves. Even though the mechanisms N fertilization increase DBM larva growth and modified larval feeding preference still unknown, $\mathrm{N}$ supply may alter the balance of plant's protein to carbohydrate ratio (P:C), or decrease levels of plants defensive, or a combination of the two (Simpson and Raubenhiemer, 1993; Bede et al., 2007). Therefore, balanced of (P:C) is essential for growth and development of many phytophagous insects.

During pupa period, treatments of $200 \mathrm{mg} / \mathrm{L}$ and 300 $\mathrm{mg} / \mathrm{L}$ of $\mathrm{N}$ had significantly shorter days compared to no treatment with the shortest pupa stage to only 2.4 days, compared to 3.78 days at no treatment. DBM pupal period varied after grown in cauliflower plant with different level of $\mathrm{N}$ fertilization that required 3.79 to 4.24 days. This is due to the plant availability had significantly affected the pupal durations of $P$. canidia (Hwang et al., 2008).

The adult DBM longevity was shown to be significantly longer with higher $\mathrm{N}$ treatment. Besides, total DBM development time shows that treatments 100 $\mathrm{mg} / \mathrm{L}, 200 \mathrm{mg} / \mathrm{L}$ and $300 \mathrm{mg} / \mathrm{L}$ gave significantly shorter at $15.59,15.68$ and 15.18 days respectively. Wang et al. (2000) found that Peregrinus maidis (Ashmead) responded to $\mathrm{N}$ fertilizer by shortening development and longer adult longevity period on corn plants grown in high N level. Similarly, Jauset et al. (2000) found that there was significantly different on the development time of immatures (from egg laying to adult emergence) of greenhouse whitefly, Trialeurodes vaporariorum (Westwood) after treated with different nitrogen level (308, 140 and $84 \mathrm{ppm})$ on tomato plants, Lycopersicon esculentum (Miller). Subsequently, 
Table 1. Means of leaves area of cabbage at week 6,9 and 12 of harvesting after treated with different $\mathrm{N}$ level

\begin{tabular}{cccc}
\hline \multirow{2}{*}{$\begin{array}{c}\text { treatments } \\
(\mathrm{mg} / \mathrm{L})\end{array}$} & Week 6 & Weaves area $\left(\mathrm{cm}^{\mathrm{a}}\right)$ \\
\cline { 2 - 4 } & $530.51 \pm 93.09^{\mathrm{a}}$ & $754.13 \pm 115.53^{\mathrm{c}}$ & Week 12 \\
\hline 0 & $580.76 \pm 100.70^{\mathrm{d}}$ & $798.25 \pm 129.62^{\mathrm{c}}$ & $763.91 \pm 132.05^{\mathrm{d}}$ \\
50 & $652.74 \pm 74.70^{\mathrm{c}}$ & $770.54 \pm 133.70^{\mathrm{c}}$ & $892.61 \pm 77.36^{\mathrm{c}}$ \\
100 & $727.03 \pm 108.52^{\mathrm{b}}$ & $824.3 \pm 143.22^{\mathrm{b}}$ & $895.84 \pm 100.59^{\mathrm{c}}$ \\
150 & $745.6 \pm 129.57^{\mathrm{b}}$ & $885.15 \pm 86.51^{\mathrm{b}}$ & $970.11 \pm 83.70^{\mathrm{b}}$ \\
200 & $825.56 \pm 90.23^{\mathrm{a}}$ & $947.81 \pm 86.51^{\mathrm{a}}$ & $1038.21 \pm 114.79^{\mathrm{a}}$ \\
300 &
\end{tabular}

*Columns and rows with the same letter were not significantly different based on Duncan's multiple range tests at a=0.05

Table 2. Effect of different $\mathrm{N}$ level on nitrogen content in leaves at 6,9 and 12 (WAT).

\begin{tabular}{cccc}
\hline $\mathrm{N}$ treatments & \multicolumn{3}{c}{ N content $(\%)$} \\
\cline { 2 - 4 }$(\mathrm{mg} / \mathrm{L})$ & Week 6 & Week 9 & Week 12 \\
\hline 0 & $1.205 \pm 0.341^{\mathrm{d}}$ & $0.356 \pm 0.12^{\mathrm{d}}$ & $0.363 \pm 0.057^{\mathrm{c}}$ \\
50 & $1.66 \pm 0.41^{\mathrm{bc}}$ & $0.51 \pm 0.22^{\mathrm{c}}$ & $0.379 \pm 0.048^{\mathrm{c}}$ \\
100 & $1.423 \pm 0.421^{\mathrm{cd}}$ & $0.597 \pm 0.175^{\mathrm{c}}$ & $0.428 \pm 0.111^{\mathrm{bc}}$ \\
150 & $1.52 \pm 0.484^{\mathrm{c}}$ & $0.713 \pm 0.335^{\mathrm{b}}$ & $0.457 \pm 0.233^{\mathrm{ab}}$ \\
200 & $1.87 \pm 0.57^{\mathrm{ab}}$ & $0.908 \pm 0.424^{\mathrm{a}}$ & $0.512 \pm 0.172^{\mathrm{a}}$ \\
300 & $2.02 \pm 0.344^{\mathrm{a}}$ & $0.924 \pm 0.42^{\mathrm{a}}$ & $0.513 \pm 0.176^{\mathrm{a}}$ \\
\hline
\end{tabular}

*Columns and rows with the same letter were not significantly different based on Duncan's multiple range tests at a=0.05

Table 3. Effect of different $\mathrm{N}$ level on glucosinolate content in leaves at 6, 9 and 12 (WAT).

\begin{tabular}{cccc}
\hline \multirow{2}{*}{$\begin{array}{c}\text { treatments } \\
(\mathrm{mg} / \mathrm{L})\end{array}$} & \multicolumn{3}{c}{ Glucosinolate content $(\mathrm{ppm})$} \\
\cline { 2 - 4 } & Week 6 & Week 9 & Week 12 \\
\hline 0 & $26.32 \pm 0.22^{\mathrm{b}}$ & $5.19 \pm 0.18^{\mathrm{d}}$ & $4.8 \pm 0.19^{\mathrm{c}}$ \\
50 & $20.32 \pm 0.31^{\mathrm{c}}$ & $13.60 \pm 0.44^{\mathrm{b}}$ & $12.29 \pm 0.05^{\mathrm{a}}$ \\
100 & $15.68 \pm 0.05^{\mathrm{d}}$ & $3.24 \pm 0.15^{\mathrm{e}}$ & $4.54 \pm 0.28^{\mathrm{c}}$ \\
150 & $35.41 \pm 0.20^{\mathrm{a}}$ & $10.22 \pm 0.22^{\mathrm{c}}$ & $2.19 \pm 0.07^{\mathrm{d}}$ \\
200 & $12.58 \pm 0.35^{\mathrm{e}}$ & $3.24 \pm 0.21^{\mathrm{e}}$ & $6.45 \pm 0.32^{\mathrm{b}}$ \\
300 & $20.22 \pm 0.57^{\mathrm{c}}$ & $18.51 \pm 0.25^{\mathrm{a}}$ & $12.6 \pm 0.24^{\mathrm{a}}$ \\
\hline
\end{tabular}

*Columns and rows with the same letter were not significantly different based on Duncan's multiple range tests at a=0.05

Table 4. Effect of $\mathrm{N}$ levels on development period of $P$. xylostella

\begin{tabular}{ccccc}
\hline $\mathrm{N}$ treatments $(\mathrm{mg} / \mathrm{L})$ & Larva period (Days) & Pupa period (Days) & Adult longevity (Days) & Development time (Days) \\
\hline 0 & $8.25^{\mathrm{a}}$ & $3.78^{\mathrm{a}}$ & $4.68^{\mathrm{c}}$ & $16.78^{\mathrm{a}}$ \\
50 & $5.5^{\mathrm{b}}$ & $3.91^{\mathrm{ab}}$ & $5.60^{\mathrm{b}}$ & $17.48^{\mathrm{a}}$ \\
100 & $5.25^{\mathrm{b}}$ & $3.83^{\mathrm{ab}}$ & $5.95^{\mathrm{b}}$ & $15.59^{\mathrm{b}}$ \\
150 & $5.6^{\mathrm{b}}$ & $3.98^{\mathrm{a}}$ & $6.05^{\mathrm{b}}$ & $17.40^{\mathrm{a}}$ \\
200 & $5.38^{\mathrm{b}}$ & $3.39^{\mathrm{b}}$ & $5.87^{\mathrm{b}}$ & $15.68^{\mathrm{b}}$ \\
300 & $4.3^{\mathrm{c}}$ & $2.4^{\mathrm{c}}$ & $7.00^{\mathrm{a}}$ & $15.18^{\mathrm{b}}$ \\
\hline
\end{tabular}

*Columns and rows with the same letter were not significantly different based on Duncan's multiple range tests at a=0.05

the composition in plant tissue influenced insect herbivores. Throop and Lerdau (2004) reported that $\mathrm{N}$ deposition may also affect the quantity of food available to herbivores, either by altering the total amount of plant tissue available or plant phenology and altering the timing of the availability of specific tissues.

\section{Conclusion}

The development of cabbage was apparently affected by higher $\mathrm{N}$ application. Higher $\mathrm{N}$ resulted in greater root length at week 6, 9 and 12. Moreover, dry weight of cabbage leaves and root increased greatly when applied with $300 \mathrm{mg} / \mathrm{L}$ of $\mathrm{N}$. The higher $\mathrm{N}$ application has increased cabbage leaves area. The leave tissue increased with the increasing of nutrient solution. At week 6, glucosinolate content in leaves was higher after treated with higher $\mathrm{N}$ level compared to 9 and 12 WAT.
Besides, development of DBM was positively influenced with $\mathrm{N}$ fertilization. Increasing $\mathrm{N}$ level significantly shorten the larva development. Higher $\mathrm{N}$ content also significantly increase the life expectancy of DBM adult. This shown that larvae on high $\mathrm{N}$ consumed food and utilized $\mathrm{N}$ more efficiently than larvae on low $\mathrm{N}$ plants. Although higher $\mathrm{N}$ fertilization resulted in the growth of plant but susceptible to insect pests. As a conclusion, higher $\mathrm{N}$ fertilization can strongly affect the host plant growth and performance of insect herbivores.

\section{Acknowledgment}

The authors would like to acknowledge the financial support provided by Ministry of Science, Technology and Innovation of Malaysia. 


\section{References}

Badenes-Perez, F.R., Gershenzon, J. and Heckel, D.G. (2014). Insect attraction versus plant defense: young leaves high in glucosinolates stimulate oviposition by a specialist herbivore despite poor larval survival due to high saponin content. PloS One, 9(4), e95766. https://doi.org/10.1371/journal.pone.0095766

Bede, J.C., McNeil, J.N. and Tobe, S.S. (2007). The role of neuropeptides in caterpillar nutritional ecology. Peptides, 28(1), 185-196. https://doi.org/10.1016/ j.peptides.2006.08.030

Boroujerdnia, M. and Ansari, N.A. (2007). Effect of Different Levels of Nitrogen Fertilizer and Cultivars on Growth, Yield and Yield Components of Romaine Lettuce (Lactuca sativa L.). Middle Eastern and Russian Journal of Plant Science and Biotechnology, 1(2), 47-53.

Corbett, G.H. and Pagden, H.T. (1941). A review of some recent entomological investigations and observations. The Malaysian Agricultural Journal, 29, 347-375.

Furlong, M.J., Wright, D.J. and Dosdall, L.M. (2013). Diamondback Moth Ecology and Management: Problems, Progress, and Prospects. Annual Review of Entomology, 58, 517-541. https://doi.org/10.1146/ annurev-ento-120811-153605.

Grzywacz, D., Rossbach, A., Rauf, A., Russell, D.A., Srinivasan, R. and Shelton, A.M. (2010). Current control methods for diamondback moth and other brassica insect pests and the prospects for improved management with lepidopteran-resistant Bt vegetable brassicas in Asia and Africa. Crop Protection, 29(1), 68-79. https://doi.org/10.1016/j.cropro.2009.08.009.

Hwang, S.Y., Liu, C.H. and Shen, T.C. (2008). Effects of plant nutrient availability and host plant species on the performance of two Pieris butterflies (Lepidoptera: Pieridae). Biochemical Systematics and Ecology, 36(7), 505-513. https:// doi.org/10.1016/j.bse.2008.03.001

Jauset, A.M., Sarasúa, M.J. Avilla, J. and Albajes, R. (2000). Effect of nitrogen fertilization level applied to tomato on the greenhouse whitefly. Crop Protection, 19(4), 255-261. https://doi.org/10.1016/ S0261-2194(00)00016-8.

Leong, A.C., Salbiah. H. and Izham, A. (2004). N and K requirements of lowland cabbage (Brassica oleracea L. var. capitata) on peat, grown under netted structure. Journal of Tropical Agriculture and Food Science, 32(1), 9-14.

DOA. (Department of Agriculture Malaysia). 2016. Vegetables and Cash Crops Statistics Malaysia 2016. Retrieved from DOA website: http// www.doa.gov.my/index/resources/aktiviti_sumber/ sumber awam/maklumat_pertanian/ perangkaan_tanaman/ perangkaan_sayur_tnmn_ladang_2016.pdf. Retrieved 27 November 2018.

Manchali, S., Kotamballi, N. Chidambara, M. and Bhimanagouda S.P. (2012). Crucial facts about health benefits of popular cruciferous vegetables. Journal of Functional Foods, 4(1), 94-106. https:// doi.org/10.1016/j.jff.2011.08.004.

Miceli, A. and Miceli, C. (2014). Effect of nitrogen fertilization on the quality swiss chard at harvest stage and during storage as minimally processed produce. Journal of Food Quality, 37(2), 125-134, https://doi.org/10.1111/jfq.12073.

Novoa, R. and Loomis, R.S. (1981). Nitrogen and plant production. Plant and Soil, 58(1-3), 177-204. https:// doi.org/10.1007/BF02180053

Petridis, A., Gasparatos, D., Haidouti, C. Paschalidis, C. and Zamanidis, P. (2012). Effects of nitrogen and boron fertilization on lettuce mineral nutrition in a calcareous soil. Communications in Soil Science and Plant Analysis, 44(1-4), 733-740. https:// doi.org/10.1080/00103624.2013.748125

Porter, A.J.R., Morton, A.M., Kiddle, G., Doughty, K.J. and Wallsgrove, R.M. (1991). Variation in the glucosinolate content of oilseed rape (Brassica napus L.) leaves. Annals of Applied Biology, 118(2), 461-467.

https://doi.org/10.1111/j.17447348.1991.tb05647.x

Shormin, T. and Kibria, M.G. (2018). Effects of nitrogen from different inorganic fertilizers on growth and yield of Indian spinach (Basella alba L.). Journal of Pharmacy and Biological Sciences, 13(5), 43-48.

Simpson, S.J. and Raubenheimer, D. (1993). The central role of the haemolymph in the regulation of nutrient intake in insects. Physiological Entomology, 18(4), 395-403. https://doi.org/10.1111/j.13653032.1993.tb00613.x

Singh, J., Upadhyay, A.K., Bahadur, A., Singh, B., Singh, K.P. and Rai, M. (2006). Antioxidant phytochemicals in cabbage (Brassica oleracea L. var. capitata). Scientia Horticulturae, 108(3), 233-237. https://doi.org/10.1016/j.scienta.2006.01.017

Song, L. and Thornalley, P.J. (2007). Effect of storage, processing and cooking on glucosinolate content of Brassica vegetables. Food and Chemical Toxicology, 45(2), 216-224. https://doi.org/10.1016/ j.fct.2006.07.021

Talekar, N.S. and Shelton, A.M. (1993). Biology, ecology, and management of the diamondback moth. Annual Review of Entomology, 38(92), 275-301. 
https://doi.org/10.1136/bmj.1.5851.492-a.

Throop, H. and Lerdau, M.T. (2004). Effects of nitrogen deposition on insect herbivory: Implications for community and ecosystem processes. Ecosystems, 7 (2), 109-133. https://doi.org/10.1007/s10021-0030225-x

Velasco, P., Cartea, M.E., Gonzalez, C., Vilar, M. and Ordas, A. (2007). Factors affecting the glucosinolate content of kale (Brassica oleracea acephala group) Journal of Agricultural and Food Chemistry, 55(3), 955-962. https://doi.org/10.1021/jf0624897 